\title{
Importance of families in nursing care for people with mental disorders: attitudes of Portuguese and Brazilian nurses
}

\author{
Importância das famílias nos cuidados de enfermagem às pessoas com \\ transtornos mentais: atitudes de enfermeiros portugueses e brasileiros \\ Importancia de las familias en el cuidado de enfermería para personas con \\ trastornos mentales: actitudes de enfermeros portugueses y brasileños
}

How to cite this article:

Nóbrega MPSS, Fernandes CSNN, Angelo M, Chaves SCS. Importance of families in nursing care for people with mental disorders: attitudes of Portuguese and Brazilian nurses. Rev Esc Enferm USP. 2020;54:e03594. doi: https://doi.org/10.1590/S1980-220X2018045603594

\author{
Maria do Perpétuo Socorro Sousa \\ Nóbrega ${ }^{1}$ \\ Carla Sílvia Neves da Nova \\ Fernandes $^{2}$

\section{Margareth Angelo ${ }^{1}$ \\ Suellen Cristina da Silva Chaves ${ }^{3}$} \\ ${ }^{1}$ Universidade de São Paulo, Escola \\ de Enfermagem, Departamento de \\ Enfermagem Materno-Infantil e \\ Psiquiátrica, São Paulo, SP, Brazil. \\ ${ }^{2}$ Universidade Fernando Pessoa, Escola \\ Superior de Saúde, Porto, Portugal. \\ ${ }^{3}$ Universidade de São Paulo, Escola de \\ Enfermagem, Programa de Pós-Graduação \\ em Enfermagem, São Paulo, SP, Brazil.
}

\section{ABSTRACT}

Objective: To characterize and compare the attitudes of nurses working in primary healthcare on the importance of involving the families of people with mental disorders in nursing care. Method: A cross-sectional study carried out in the cities of Porto (Portugal) and São Paulo (Brazil). Data was collected in 2018 using the "The Importance of Families in Nursing Care - Nurses'Attitudes" scale. Results: There were 250 Portuguese and 250 Brazilian nurses who participated. The total average score on the scale was 86.0 in Portugal and 82.1 in Brazil (with a maximum possible of 104). The variables which influence a more favorable attitude towards the involvement of families in nursing care in the Portuguese context are academic qualifications and age, while in Brazil they are training on Family Nursing and the weekly workload. Conclusion: Participants in both countries have a positive attitude towards families, which constitutes a first step towards their integration in nursing care and also enables advances in mental health politics.

\section{DESCRIPTORS}

Mental Disorders; Family Nursing; Primary Care Nursing; Psychiatric Nursing; Caregivers.
Corresponding author:

Maria do Perpétuo S. S. Nóbrega

Universidade de São Paulo, Escola de

Enfermagem, Departamento de Enfermagem

Materno-Infantil e Psiquiátrica.

Av. Dr. Arnaldo, 419

CEP 05403-000 - São Paulo, SP, Brazil.

perpetua.nobrega@usp.br
Received: 10/17/2018

Approved: 10/07/2019 


\section{INTRODUCTION}

Attitudes that nurses adopt towards the family condition the nursing care process ${ }^{(1)}$. It is known that patients' diseases affect the health of families, and their functioning and coping strategies have a strong influence on the way the person experiences the disease ${ }^{(2-5)}$; this reciprocal impact is visible in studies developed in contexts of care practices, as well as in the different health-disease transitions experienced within the family ${ }^{(6-10)}$. In view of this, nursing care must be processed through a systemic approach in which the totality is seen as being greater than its parts, and where the properties or behaviors of the family system are better understood ${ }^{(11)}$.

An indicator to assess the quality of the relationship between health professionals and family members is the attitudes related to their involvement in care ${ }^{(3,5)}$. Maintaining a favorable attitude is an important prerequisite for inviting, involving and improving the interaction between nurses and families in nursing care ${ }^{(3)}$. An interaction which conceives families as members of the health team and considers them as a care unit, subtracting the perspective of patriarchy and paternalism, enables a relationship of dignity, respect, partnership, information sharing and collaboration ${ }^{(12)}$.

Research developed on nurses'attitudes towards the family in different countries and in different care contexts, namely primary care ${ }^{(1,3,10)}$, hospital care ${ }^{(4-5)}$, pediatrics $^{(13-14)}$, oncology $y^{(9)}$, emergencies $^{(8,15)}$, homes ${ }^{(16)}$, intensive care ${ }^{(7)}$ and psychiatry ${ }^{(17)}$, show that when nurses believe that family members are important in the care process, the likelihood of initiating favorable interactions with them increases, and that these interactions are influenced by their attitudes regarding the importance of including them in care ${ }^{(3-5)}$. There are several instruments used to understand the phenomenon within the scope of these studies ${ }^{(1,3-5,7,10,13-14,16-20)}$, with the most frequent being the "Families Importance in Nursing Care - Nurses' Attitudes" (FINC-NA) scale developed in Sweden ${ }^{(3)}$.

Studies support the care context as a variable which influences incorporating the family in care. Nurses who work with people with mental disorders know that families experience feelings of rejection and stigmatization ${ }^{(17)}$, even providing substantial amounts of care and support to the sick family member ${ }^{(21)}$. A review study on the knowledge, skills and attitudes of mental health nurses who work with families highlights that family members have a valuable role in support, but are often marginalized by health professionals, with educational and skills deficits being cited as major reasons ${ }^{(22)}$.

In the scope of primary healthcare, Brazil and Portugal underwent significant reforms between 2005 and 2006. The reform of Primary Healthcare in Portugal (equivalent to Primary Healthcare in Brazil), was one of the most successful reforms in the country ${ }^{(23)}$. The National Primary Healthcare Policy in Brazil was instituted in 2006 and has recently undergone changes, emphasizing the actions to promote access to the health system, which should take place in a privileged way, especially through the Family Health Strategy ${ }^{(24)}$.

Mental Health policies are currently grounded in community-based care conducted through social inclusion programs, encouraging the autonomy and citizenship of people with mental disorders under the logic of psychosocial rehabilitation $^{(25)}$. In this perspective, more emphasis on family involvement in care and the provision of informal support networks for users of mental health services should be considered ${ }^{(26)}$. However, the operationalization of Mental Healthcare in the field of Primary Healthcare, especially conducted by nurses, implies transforming the vision that they have in relation to users and their families. Thus, being aware of the importance of family participation in the care of people with mental disorders, and in view of the changes in two important public policies in these two countries, this study aims to characterize and compare the attitudes of nurses working in primary healthcare on the importance to involve the families of people with mental disorders in nursing care.

\section{METHOD}

\section{STUDY DESIGN}

A cross-sectional descriptive study which is part of the multicenter project "Attitudes of nursing professionals working in Primary Healthcare in facing mental disorders"(Atitudes APS), conducted by researchers from Brazil and Portugal.

\section{Population}

There were 250 nurses working in healthcare units in six Family Health Units of the Northern Regional Health Administration in Porto city, Portugal, and another 250 nurses working in 69 Basic Health Units (traditional and/ or with Family Health Strategy) in the six Regional Health Department Coordinating bodied of the municipality of São Paulo, Brazil, who participated in this study. They were all nurses working in management and/or care provision, regardless length of professional experience or service.

\section{DATA COLLECTION}

Data collection was conducted simultaneously in both countries between February-April 2018, by means of a questionnaire with the following socio-demographic data: gender, age, marital status, academic qualifications, time of education, length of experience in the current service, training in family nursing, weekly workload, experience/ frequency of encountering people with mental disorders.

The Portuguese version of the FINC-NA ${ }^{(3)}$, which after being translated and validated was called " $A$ Importância das Familias nos Cuidados de Enfermagem - Atitudes dos Enfermeiros (IFCE-AE)"(1), was applied to verify the attitudes of Portuguese nurses towards the family in caring for people with mental disorders and how their attitudes show this importance. The version with semantic equivalence to Brazilian Portuguese was used for data collection with Brazilian nurses ${ }^{(13)}$. The choice of FINC-NA in the present study was due to the fact that it provides a direct and pragmatic method of measuring and comparing variables. It consists of 26 items with 4 Likert-type answer options (strongly disagree, disagree, agree, strongly agree), and the score for each item ranges from 1 to 4 . Its range varies from 
26 to 104 for the entire instrument, where the higher the score, the better the attitudes towards families.

The FINC-NA includes three subscales: 'Family: responsive partner and coping resource', consisting of 12 items with the score ranging from 12 to 48 , where the family is valued for its characteristics, potential and strengths, an important source of information, interlocutor, with whom a therapeutic dialogue can be established, valuing their involvement in care; 'Family: resource of nursing care', composed of 10 items with the score ranging from 10 to 40, which places the family as the holder of strengths and resources to collaborate in decision-making, partner, also seen as the target of care; and finally, 'Family: burden', composed of 04 items with the score varying from 4 to 16, which implies in a negative attitude towards the family, considering their inclusion in care as undesirable ${ }^{(13)}$. The estimated internal consistency for the present study by Cronbach's alpha was 0.918 for the total scale, which was higher than the original version $(0.88)^{(3)}$, and than the Portuguese versions $(0.87)^{(1)}$.

\section{DATA ANALYSIS AND PROCESSING}

The data were coded and inserted into the Statistical Package for the Social Sciences software version 24. Mean and standard deviation (SD), identifying the distribution of the two samples, the Mann-Whitney test, a statistical significance of $\mathrm{p}<0.05$, and confidence interval of $95 \%$ were used for descriptive statistics.

\section{ETHICAL ASPECTS}

The project was approved by the Human Research Ethics Committee of Faculdade Fernando Pessoa (Opinion no. 155-2017) in Portugal, while the project was also approved by the Human Research Ethics Committee of the School of Nursing at the Universidade de São Paulo (Opinion 2.384.303), in accordance with Resolution no. 466/2012, of the National Health Council in Brazil in 2017. The request to conduct the study was directed to the coordination of each service by sending the study link through the institutional e-mail to nurses, comprising a Googledocs form with a description of the objective, collection instruments and consent form.

\section{RESULTS}

There was a predominance of female professionals in both contexts (Portugal - 82.8\%, Brazil - 85.6\%), with an average age of 42.0 years in Portugal (Standard deviation = 7.7) and 36.3 in Brazil (standard deviation = 7.7). The majority of the samples in both countries are married (Portugal - 71.2\%, Brazil - 57.2\%). Regarding professional characteristics, a minority have higher academic levels (Portugal: 18.0\% Master's, and 1.2\% Doctorate; Brazil: 4.0\% Master's and $0.8 \%$ Doctorate), while the experience and training time is less in Brazil. The weekly workload in Portugal is 35 hours (54.4\%), while in Brazil the majority have 40 hours a week (62.8\%). Training in family nursing is slightly higher in Portugal (Portugal - 75.6\%, Brazil - 63.6\%). In relation to the experience with people with mental disorders in primary healthcare, it is mentioned by $94.8 \%$ of the participants in Portugal, while it is only mentioned by $63.6 \%$ in Brazil, with a higher frequency of daily contact in Brazil (Daily: Portugal - 27.2\%, Brazil - 63.6\%) (Table 1).

Table 1 - Sociodemographic characterization of the Atitudes APS study sample - Porto, Portugal/São Paulo, Brazil, 2018.

\begin{tabular}{|c|c|c|c|c|c|c|c|c|}
\hline \multirow{2}{*}{ Variables } & \multicolumn{4}{|c|}{ Portugal $(n=250)$} & \multicolumn{4}{|c|}{ Brazil $(n=250)$} \\
\hline & $\mathbf{N}$ & $\%$ & Mean & SD & $\mathbf{N}$ & $\%$ & Mean & SD \\
\hline \multicolumn{9}{|l|}{ Gender } \\
\hline Male & 43 & 17.2 & & & 36 & 14.4 & & \\
\hline Female & 207 & 82.8 & & & 214 & 85.6 & & \\
\hline Age (years) & & & 42.0 & 7.7 & & & 36.3 & 7,7 \\
\hline \multicolumn{9}{|l|}{ Civil status } \\
\hline Single & 23 & 9.2 & & & 88 & 35.2 & & \\
\hline Married & 178 & 71.2 & & & 143 & 57.2 & & \\
\hline Common-law & 23 & 9.2 & & & - & - & & \\
\hline Separated & 3 & 1.2 & & & 2 & 0.8 & & \\
\hline Divorced & 20 & 8.0 & & & - & - & & \\
\hline Widowed & 3 & 1.2 & & & 17 & 6.8 & & \\
\hline \multicolumn{9}{|c|}{ Academic qualifications } \\
\hline Graduation & 1 & 0.4 & & & 24 & 9.6 & & \\
\hline Bachelor degree & 201 & 80.4 & & & 214 & 85.6 & & \\
\hline Master's degree & 45 & 18.0 & & & 10 & 4.0 & & \\
\hline Doctorate degree & 3 & 1.2 & & & 2 & 0.8 & & \\
\hline \multicolumn{9}{|c|}{ Time since graduation } \\
\hline$<1$ year & 5 & 2.0 & & & 2 & 0.8 & & \\
\hline 1 to 5 years & 50 & 20.0 & & & 76 & 30.4 & & \\
\hline 5 to 10 years & 33 & 13.2 & & & 98 & 39.2 & & \\
\hline 10 to 20 years & 87 & 34.8 & & & 63 & 25.2 & & \\
\hline$>20$ years & 75 & 30.0 & & & 11 & 4.4 & & \\
\hline \multicolumn{9}{|c|}{ Time in the current service } \\
\hline$<1$ year & 7 & 2.8 & & & 38 & 15.2 & & \\
\hline 1 to 5 years & 50 & 20.0 & & & 107 & 42.8 & & \\
\hline 5 to 10 years & 65 & 26.0 & & & 66 & 26.4 & & \\
\hline 10 to 20 years & 91 & 36.4 & & & 33 & 13.2 & & \\
\hline$>20$ years & 37 & 14.8 & & & 6 & 2.4 & & \\
\hline \multicolumn{9}{|l|}{ Weekly workload } \\
\hline $20 \mathrm{H}$ & 6 & 2.4 & & & - & - & & \\
\hline $30 \mathrm{H}$ & - & - & & & 39 & 15.6 & & \\
\hline $35 \mathrm{H}$ & 136 & 54.4 & & & - & - & & \\
\hline $36 \mathrm{H}$ & 67 & 26.8 & & & 31 & 12.4 & & \\
\hline $40 \mathrm{H}$ & 40 & 16.0 & & & 157 & 62.8 & & \\
\hline $44 \mathrm{H}$ & 1 & 0.4 & & & 23 & 9.2 & & \\
\hline \multicolumn{9}{|c|}{ Family Nursing Training } \\
\hline No & 61 & 24.4 & & & 91 & 36.4 & & \\
\hline Yes & 189 & 75.6 & & & 159 & 63.6 & & \\
\hline \multicolumn{9}{|c|}{ Experience with people with mental disorders } \\
\hline No & 13 & 5.2 & & & 91 & 36.4 & & \\
\hline Yes & 237 & 94.8 & & & 159 & 63.6 & & \\
\hline \multicolumn{9}{|c|}{ Frequency of encountering people with mental disorders } \\
\hline Daily & 65 & 27.2 & & & 159 & 63.6 & & \\
\hline Weekly & 82 & 34.3 & & & 76 & 30.4 & & \\
\hline Monthly & 67 & 28.0 & & & 15 & 6.0 & & \\
\hline Ocasionally & 25 & 10.5 & & & - & - & & \\
\hline
\end{tabular}

Note: $n=500$ nurses.

\section{NURSES' ATTITUDES TOWARDS FAMILIES}

The total scores of the FINC-NA were used in order to obtain an overall measure of the profile of each nurse, with the mean point being 65 . The total mean score was higher than the average value in both countries, being slightly higher in the Portuguese context (Portugal - 86.0, Brazil-82.1), indicating that nurses mostly have a favorable attitude about the importance of families in nursing care. As for the mean values for each subscale, the mean score in the "Family: responsive partner and coping resource" dimension is slightly higher in Portugal (Portugal - 40.2, Brazil - 38.1), as well as in the "Family: resource of nursing care" dimension (Portugal - 33.5, Brazil - 31.9), while the values in the "Family: burden" dimension are practically identical (Portugal - 12.3, Brazil - 12.1) (Table 2). 
Table 2 - Total and Dimensions of the FINC-NA Atitudes APS study - Porto, Portugal/São Paulo, Brazil, 2018.

\begin{tabular}{|c|c|c|c|c|c|c|}
\hline \multirow{2}{*}{ Dimension } & \multicolumn{3}{|c|}{ Portugal $(n=250)$} & \multicolumn{3}{|c|}{ Brazil $(n=250)$} \\
\hline & Mean & SD & Range & Mean & SD & Range \\
\hline Scale total (26 items) & 86.0 & 9.3 & $61-104$ & 82.1 & 8.4 & 40-101 \\
\hline $\begin{array}{l}\text { Family: responsive } \\
\text { partner and coping } \\
\text { resource (12 items) }\end{array}$ & 40.2 & 5.1 & & 38.1 & 4.6 & $13-48$ \\
\hline $\begin{array}{l}\text { Family: resource of } \\
\text { nursing care ( } 10 \text { items) }\end{array}$ & 33.5 & 3.8 & $21-40$ & 31.9 & 3.7 & $14-40$ \\
\hline Family: burden (4 items) & 12.3 & 1.9 & $4-16$ & 12.1 & 1.5 & $8-16$ \\
\hline
\end{tabular}

* Dimension range: Total scale: 26-104 (Midpoint 65); Family as a dialoguing partner $=12$ to 48 (Midpoint 30); Family as a resource of nursing care $=10$ to 40 (Midpoint 25; Family as a burden $=4$ to 16 (Midpoint 10). Note: $\mathrm{n}=500$ nurses.

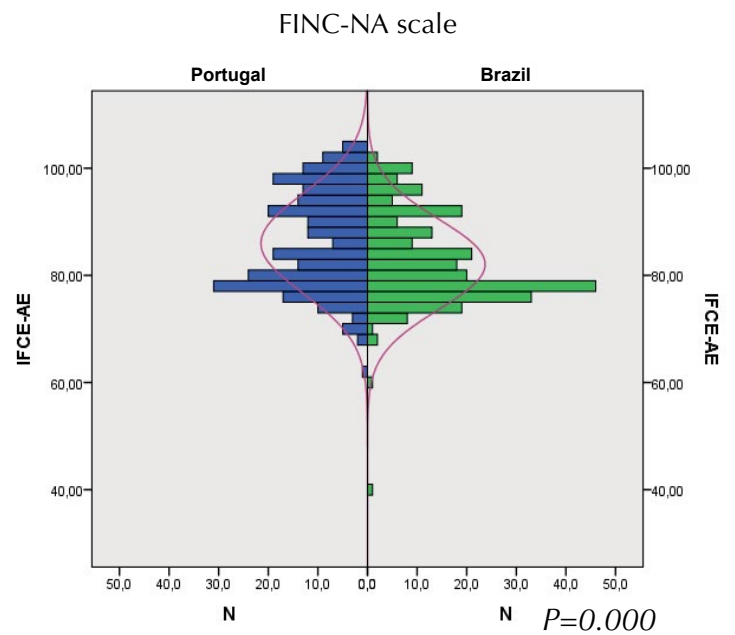

Dimension: Family: resource of nursing care

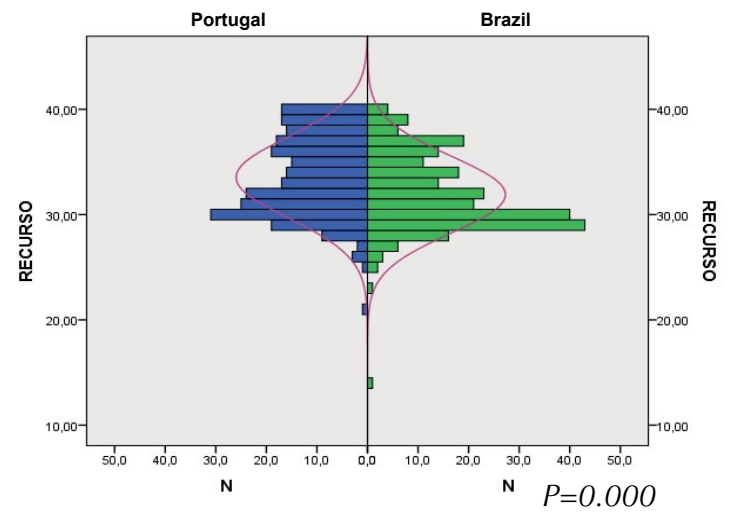

Figure 1 - FINC-NA, Atitudes APS study.

Table 3 shows the correlational analyzes between sociodemographic and professional variables and the scores of the total scale and subscales. It is observed that age, academic qualifications, training time and conversely the weekly workload influence the overall attitude of nurses in the Portuguese context. In Brazilian participants there is a correlation with training on family nursing, the frequency with which they encounter people with mental disorders, and conversely with the weekly workload. The training
Despite the values of the overall scale and its dimensions showing values which exceed the midpoint, Table 2 and Figure 1 show a different distribution in the two countries, namely regarding the distribution range.

Applying inferential statistics validates that the two samples have different distributions for each scale and subscale (Total scale: $\mathrm{p}=0.000$; Responsive partner and coping resource dimension: $\mathrm{p}=0.00$; Resource of nursing care dimension: $p=0.00$ ), except for the family as a burden $(\mathrm{p}=0.406)$.

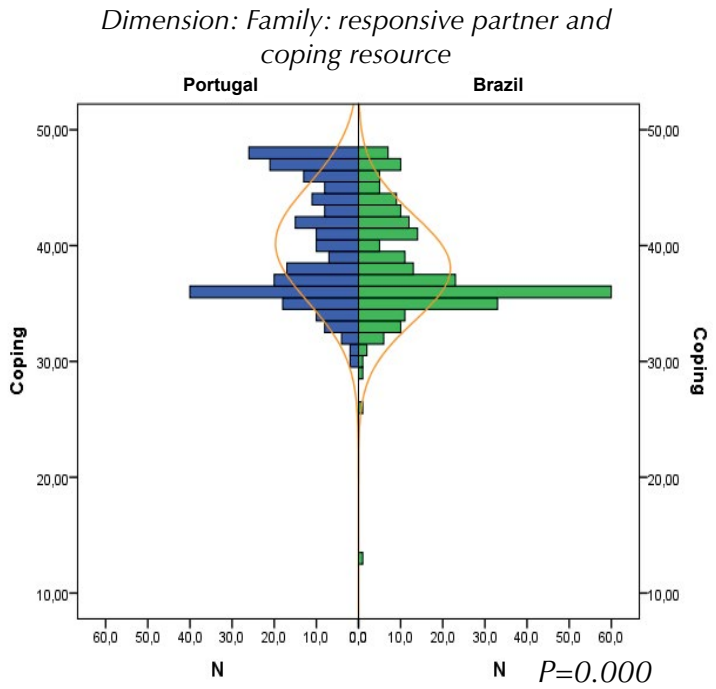

Dimension: Family: burden

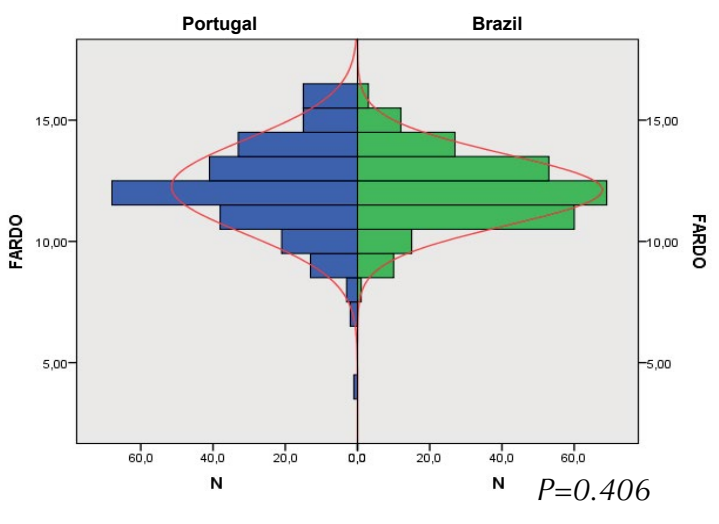

$p<.05$

on family nursing is correlated with the "Family: responsive partner and coping resource" and "Family: resource of nursing care" dimensions in the Brazilian context, while these dimensions are influenced by age, training time and academic qualifications in the Portuguese context. In the "Family: burden" dimension, age and training time influence the attitudes of Portuguese participants, while the weekly workload influences both groups of participants in this dimension. 
Table 3 - Correlation of scale and subscale data with sociodemographic variables, Atitudes APS study - Porto, Portugal/São Paulo, Brazil, 2018.

\begin{tabular}{|c|c|c|c|c|c|}
\hline \multirow[b]{2}{*}{ Scale and Subscales } & \multirow[b]{2}{*}{ Variables } & \multicolumn{2}{|c|}{ Portugal } & \multicolumn{2}{|c|}{ Brazil } \\
\hline & & $\begin{array}{l}\text { Pearson's } \\
\text { Correlation }\end{array}$ & Significance & $\begin{array}{l}\text { Pearson's } \\
\text { Correlation }\end{array}$ & Significance \\
\hline \multirow{7}{*}{ FINC-AN scale } & Age & $0.152 *$ & 0.016 & -0.182 & 0.004 \\
\hline & Academic qualifications & $0.271 * *$ & 0.000 & 0.043 & 0.501 \\
\hline & Time since graduation & $0.192 * *$ & 0.002 & 0.014 & 0.826 \\
\hline & Weekly workload & $-0.163^{* *}$ & 0.010 & $0.215^{* *}$ & 0.001 \\
\hline & Family nursing training & -0.009 & 0.887 & $0.160 *$ & 0.011 \\
\hline & $\begin{array}{l}\text { Experience with people with mental } \\
\text { disorders }\end{array}$ & 0.017 & 0.793 & 0.086 & 0.174 \\
\hline & $\begin{array}{l}\text { Frequency of encountering people with } \\
\text { mental disorders }\end{array}$ & -0.056 & 0.393 & $-0.198 * *$ & 0.002 \\
\hline \multirow{7}{*}{$\begin{array}{l}\text { Family as a dialoguing } \\
\text { partner and coping } \\
\text { resource }\end{array}$} & Age & $0.146 * *$ & 0.021 & $-0.131 *$ & 0.038 \\
\hline & Academic qualifications & $0.227^{* *}$ & 0.000 & -0.001 & 0.981 \\
\hline & Time since graduation & $0.169 * *$ & 0.007 & -0.003 & 0.906 \\
\hline & Weekly workload & $-0.138^{*}$ & 0.029 & $0.153 *$ & 0.015 \\
\hline & Family nursing training & -0.010 & 0.874 & $0.154 *$ & 0.015 \\
\hline & $\begin{array}{l}\text { Experience with people with mental } \\
\text { disorders }\end{array}$ & 0.034 & 0.589 & 0.109 & 0.086 \\
\hline & $\begin{array}{l}\text { Frequency of encountering people with } \\
\text { mental disorders }\end{array}$ & -0.087 & 0.488 & $-0.188^{* *}$ & 0.003 \\
\hline \multirow{7}{*}{$\begin{array}{l}\text { Family as a resource of } \\
\text { nursing care }\end{array}$} & Age & 0.080 & 0.208 & $0.176^{* *}$ & 0.005 \\
\hline & Academic qualifications & $0.232 * *$ & 0.000 & 0.0050 & 0.436 \\
\hline & Time since graduation & $0.133^{*}$ & 0.036 & 0.041 & 0.518 \\
\hline & Weekly workload & $-0.137^{*}$ & 0.030 & $0.205^{* *}$ & 0.001 \\
\hline & Family nursing training & 0.014 & 0.825 & $-0.133^{*}$ & 0.036 \\
\hline & $\begin{array}{l}\text { Experience with people with mental } \\
\text { disorders }\end{array}$ & 0.029 & 0.643 & 0.071 & 0.261 \\
\hline & $\begin{array}{l}\text { Frequency of encountering people with } \\
\text { mental disorders }\end{array}$ & -0.075 & 0.245 & $-0.143^{*}$ & 0.024 \\
\hline \multirow{7}{*}{ Family as a burden } & Age & $0.248^{* *}$ & 0.000 & -0.090 & 0.157 \\
\hline & Academic qualifications & 0.116 & 0.068 & 0.010 & 0.870 \\
\hline & Time since graduation & $0.268^{* *}$ & 0.000 & 0.050 & 0.429 \\
\hline & Weekly workload & $-0.148 *$ & 0.019 & $0.125^{*}$ & 0.049 \\
\hline & Family nursing training & 0.010 & 0.870 & 0.075 & 0.235 \\
\hline & $\begin{array}{l}\text { Experience with people with mental } \\
\text { disorders }\end{array}$ & -0.055 & 0.387 & 0.082 & 0.196 \\
\hline & $\begin{array}{l}\text { Frequency of encountering people with } \\
\text { mental disorders }\end{array}$ & 0.073 & 0.263 & -0.087 & 0.169 \\
\hline
\end{tabular}

The correlation is significant at the 0.01 (bilateral) level.**

The correlation is significant at the 0.05 (bilateral) level."

\section{DISCUSSION}

As a concept, attitude refers to an assessment and predisposition to respond to a social object. Positive attitudes of nurses about the families of patients are an important prerequisite for inviting and including families in nursing care and influence the quality of the relationship ${ }^{(3-4)}$. As already mentioned, the attitudes associated with the importance of including families in nursing care have been widely studied, although to a lesser extent in the specific context of people with mental disorders and specifically in primary healthcare settings.

The encouragement of national and international policies in implementing care and monitoring people with mental disorders in the community will imply in an increase in the needs of these patients in health units, as well as a greater concern for their families who experience social, cultural, physical and psychological problems ${ }^{(23)}$. In addition, the use of informal support networks, preferably the family, is advocated as part of the effort for more services oriented to recovery, recognizing that families provide an enormous amount of support to people who suffer from mental problems, whether emotional, practical or financial ${ }^{(21)}$. However, it is necessary to develop a good relationship with families and positive attitudes towards them for family-focused care $^{(22)}$.

Nurses' attitudes are important to involve families in care and fundamental to the quality of the interventions provided, and when they are positive they encourage nurses to become more involved in therapeutic conversations with families ${ }^{(17)}$. Considering the guidelines of the World Health Organization regarding the integration of mental health in primary healthcare and the similarity in the panorama of mental health policies in Brazil-Portugal, the analysis of nurses' attitudes comprises elements which support consolidating the agenda for deinstitutionalization common to two scenarios, and shows that although attitudes are slightly higher in Portuguese participants and with a smaller range of variation, they are positive in both countries. 
It is hypothesized that the high number of Brazilian nurses who deny the experience of working with people with mental disorders happens due to their shorter professional experience when compared to the Portuguese reality. In addition, the management of primary healthcare services in the reality of the municipality of São Paulo has generally taken place through indirect management, which means through Social Health Organizations that manage a large part of public services. There is a greater turnover of its workers due to its organizational dynamics, which can lead to negative and harmful results for service users, for example the non-establishment of a bond, a phenomenon which compromises evaluating the real health needs of an individual in the field of mental health and distances professionals from that population in particular.

In a study conducted to try to explore the attitudes towards family members of people with mental disorders, specifically with dementia in a home in Korea (although with a different instrument), the authors report that nursing assistants showed more negative attitudes in relation to family members than nurses ${ }^{(16)}$. A study conducted in Ireland using the FINC-NA scale with nurses working in psychiatric hospitalizations obtained higher total values than those obtained in the present study. The average score in adult psychiatric hospitalizations is 87.4 , the average score in rehabilitation is 92.2 , and the average score in psychiatric hospitalizations of children and adolescents is $97.6^{(17)}$.

With regard to the correlation of attitudes towards families and social and professional variables, the results show that there is a relationship between training on family nursing and the overall attitude, as well as on the "Family: responsive partner and coping resource" and "Family: resource of nursing care" dimensions, but only for Brazilian participants. Similar results were obtained in a study carried out with primary healthcare nurses in Portugal, although more clearly in the "Family: responsive partner and coping resource" dimension ${ }^{(10)}$. Other studies corroborate this influence ${ }^{(1,13)}$.

The influence of academic qualifications was observed in the Portuguese context on the overall score of the scale, as well as on the "Family: responsive partner and coping resource" and "Family: resource of nursing care" dimensions. As the author says, in a study developed in a Portuguese context these results may be related to content about the family being included in graduate programs ${ }^{(10)}$.

However, while the importance of care focused on the family is recognized and described by nurses, according to the families' experiences the care relationship has not developed in the same way ${ }^{(22)}$, as there is still tension between family members and mental health service providers ${ }^{(21)}$. A solution may be in education, which requires more detailed information about the knowledge, skills and attitudes necessary to work with a focus on the family in order to develop further ${ }^{(22)}$.

It was observed that the positive correlation with the weekly workload (40 hours) in the experience of Brazilian nurses leads to positive attitudes, both in the overall calculation and in the FINC-NA dimensions, inversely to the Portuguese perspective with the weekly workload (35 hours).
These findings merit further study, but in any case it is hypothesized that the weekly workload of Brazilian nurses in Primary Healthcare structured to meet the context of the Family Health Strategy (FHS) ${ }^{(24)}$ with a focus on health promotion puts professionals in greater contact with the families of people with mental disorders; furthermore, the FHS demands effective outcomes in terms of interventions conducted and linking professionals to the population, leading them to better understand their care needs, despite the lack of qualification in the scope of mental health in the country ${ }^{(27)}$.

Even though the training of nurses in the Portuguese reality has followed the changes made in the health system also based on health promotion and the growing orientation towards primary healthcare in Family Health Units, the low recruitment for Primary Healthcare is evident, as well as a devaluation in the role of nurses in care which brings them closer to citizens, even though they are able to assume responsibilities and make decisions when facing more complex situations $^{(28)}$, thus constituting aspects which can result in negative attitudes of these professionals in relation to the inclusion of families in care actions.

\section{CONCLUSION}

The study has limitations in the use of a self-administered questionnaire, which may have led to an overvaluation of some of the findings, warning of a possible dichotomy between the speeches and practices, and that those who responded to the study were more aware of the theme, which in turn makes it difficult to recognize the total population and affects the possibility of generalizing the results to all nurses.

The attitude of primary healthcare nurses in relation to the importance of involving families in their care is fundamental to the quality of the intervention offered to family members. Enabling approximation of these professionals who work in primary healthcare to providing care to people with mental disorders and their families can expand the way of working with this population and modify the current exclusion and rejection pattern which is still rooted in culture, thereby making it possible to raise awareness for a new modus operandi of care and to advance in mental health policy. There are still some gaps about why patient and family-centered care has not yet been successfully implemented, and why it is still not uncommon to hear patients and family members assessing relationships with healthcare providers as being indifferent and difficult.

In summary, it was possible to observe that the participants in both countries have a positive attitude towards families, which is a first step towards integrating families in care. Thus, the results represent a first step as an indicator of situational assessment to support proposals for interventions. It is suggested to continue studies with the theme in order to deepen how the family care practice develops and builds, taking into account that the family nursing training process must be different for nurses who already have a supportive attitude in relation to families. 


\section{RESUMO}

Objetivo: Caracterizar e comparar as atitudes dos enfermeiros que atuam em cuidados de saúde primários sobre a importância de envolver as famílias da pessoa com transtorno mental nos cuidados de enfermagem. Método: Estudo transversal, realizado nas cidades de Porto e São Paulo. Dados coletados em 2018 por meio da escala "A Importância das Famílias nos Cuidados de Enfermagem Atitudes dos Enfermeiros". Resultados: Participaram 250 enfermeiros Portugueses e 250 Brasileiros. A pontuação média total da escala obteve um escore 86,0 em Portugal e 82,1 no Brasil (máximo possível 104). As variáveis que influenciam uma atitude mais favorável em relação ao envolvimento das famílias na assistência de enfermagem no contexto português são as habilitações acadêmicas e idade, enquanto no brasileiro são a formação sobre Enfermagem de Família e a carga semanal de trabalho. Conclusão: Em ambos os países os participantes têm uma atitude positiva para com as famílias, o que constitui uma primeira etapa para a integração destas nos cuidados de enfermagem e também possibilita avanços na política de saúde mental.

\section{DESCRITORES}

Transtornos Mentais; Enfermagem Familiar; Enfermagem de Atenção Primária; Enfermagem Psiquiátrica; Cuidadores.

\section{RESUMEN}

Objetivo: Caracterizar y comparar las actitudes de los enfermeros que actúan en cuidados de salud primarios acerca de la importancia de envolver las familias de la persona con trastorno mental en los cuidados de enfermería. Método: Estudio transversal, realizado en las ciudades de Porto y São Paulo. Datos colectados en 2018 por medio de la escala "La Importancia de las Familias en los Cuidados de Enfermería-Actitudes de los Enfermeros". Resultados: Participaron 250 enfermeros portugueses y 250 brasileños. La puntuación media total de la escala presentó un score 86,0 en Portugal y 82,1 en Brasil (máximo posible 104). Las variables que influencian una actitud más favorable en relación con el envolvimiento de las familias en la asistencia de enfermería en un contexto portugués son las habilitaciones académicas y edad, mientras que en lo brasileño son el entrenamiento acerca de la Enfermería de la Familia y la carga semanal del trabajo. Conclusión: En los dos países los participantes tienen una actitud positiva para con las familias, o que constituye una primera etapa para la integración de estas en los cuidados de enfermería y también posibilita avanzos en la política de salud mental

\section{DESCRIPTORES}

Transtornos Mentales; Enfermería Familiar; Enfermería de Atención Primaria; Enfermería Psiquiátrica; Cuidadores..

\section{REFERENCES}

1. Oliveira PCM, Fernandes HIV, Vilar AISP, Figueiredo MHJS, Ferreira MMSRS, Martinho MJCM, et al. Attitudes of nurses towards families: validation of the Scale Families' Importance in Nursing Care-Nurses Attitudes. Rev Esc Enferm USP. 2011; 45(6):1331-7. DOI: http://dx.doi. org/10.1590/S0080-62342011000600008

2. Mahrer-Imhof R, Bruylands M. Is it beneficial to involve family member? A literature review to psychosocial interventions in familycentered nursing. Pflege. 2014;27(5):285-96. DOI: 10.1024/1012-5302/a000376

3. Benzein E, Johansson P, Årestedt KF, Saveman BI. Nurses' Attitudes About the importance of families in nursing care: a survey of Swedish nurses. J Fam Nurs. 2008;14(2):162-80. DOI: 10.1177/1074840708317058

4. Blöndal K, Zoëga S, Hafsteinsdottir JE, Olafsdottir OA, Thorvardardottir AB, Sveinsdóttir H, et al. Attitudes of registered and licensed practical nurses about the importance of families in surgical hospital units: findings from the Landspitali University Hospital Family Nursing Implementation Project. J Fam Nurs. 2014;20(3):355-75. DOI: 10.1177/1074840714542875

5. Fernandes CS, Gomes JAP, Martins MM, Gomes BP, Gonçalves LHT. The importance of families in nursing care: nurses' attitudes in the hospital environment. Rev Enf Referência. 2015;(7):21-30. DOI: http:// dx.doi.org/10.12707/RIV15007

6. Borba LO, Paes MR, Guimarães AN, Labronici LM, Maftum MA. The family and the mental disturbance carrier: dynamics and their family relationship. Rev Esc Enferm USP. 2011;45(2):442-9. DOI: http://dx.doi.org/10.1590/S0080-62342011000200020

7. Chaves RGR, Sousa FGM, Silva ACO, Santos GFL, Fernandes HIVM, Cutri CMS. Importance of the family in the care process: attitudes of nurses in the context of intensive therapy. J Nurs UFPE. 2017;11(12):4989-98. DOI: https://doi.org/10.5205/1981-8963v11i12a22285p4989-4998-2017

8. Ferrara G, Ramponi D, Cline TW. Evaluation of physicians' and nurses' knowledge, attitudes, and compliance with family presence during resuscitation in an emergency department setting after an educational intervention. Adv Emerg Nurs J. 2016;38(1):32-42. DOI: 10.1097/ TME.0000000000000086

9. Laidsaar-Powell R, Butow P, Bu S, Fisher A, Juraskova I. Oncologists' and oncology nurses' attitudes and practices towards family involvement in cancer consultations. Eur J Cancer Care (Engl). 2017;26(1):e12470. DOI: 10.1111/ecc.12470

10. Silva MANCGMM, Costa MASM, Silva MMFP. A família em cuidados de saúde primários: caracterização das atitudes dos enfermeiros. Rev Enf Referência. 2013;serllI(11):19-28. DOI: http://dx.doi.org/10.12707/RIII13105

11. Svavarsdottir EK, Sigurdardottir AO, Konradsdottir E, Tryggvadottir GB. The impact of nursing education and job characteristics on nurse's perceptions of their family nursing practice skills. Scand J Caring Sci. 2018;32(4):1297-307. DOI: 10.1111/scs.12573

12. Bell JM. Family nursing is more than family centered care. J Fam Nurs. 2013;19(4):411-7. DOI: 10.1177/1074840713512750

13. Angelo M, Cruz AC, Mekitarian FFP, Santos CCS, Matinho MJCM, Martins MMFPS. Nurses' attitudes regarding the importance of families in pediatric nursing care. Rev Esc Enferm USP. 2014;48(n.spe):74-9. DOI: 10.1590/S0080-623420140000600011

14. Pascual Fernández MC, Ignacio Cerro MC, Cervantes Estévez L, Jiménez Carrascosa MA, Medina Torres M, García Pozo AM. Cuestionario para evaluar la importancia de la familia en los cuidados de enfermería. Validación de la versión española (FINC-NA). An Sist Sanit Navar. 2015;38(1):31-9. DOI: 10.23938/ASSN.0051

15. Abdar M, Rafiei H, Amiri M, Tajadini M, Tavan A, Rayani F, et al. Iranian nurse attitudes towards the presence of family members during CPR. Br J Card Nurs. 2016;11(9):438-43. DOI:10.12968/bjca.2016.11.9.438

16. Park M. Nursing staff stress from caregiving and attitudes toward family members of nursing home residents with dementia in Korea. Asian Nurs Res. 2010;4(3):130-41. DOI: 10.1016/S1976-1317(10)60013-8 
17. Sveinbjarnardottir EK, Svavarsdottir EK, Saveman BI. Nurses attitudes towards the importance of families in psychiatric care following an educational and training intervention program. J Psychiatr Ment Health Nurs. 2011;18(10):895-903. DOI: 10.1111/j.13652850.2011.01744.x

18. Gusdal AK, Josefsson K, Adolfsson ET, Martin L. Nurses' attitudes toward family importance in heart failure care. Eur J Cardiovasc Nurs. 2017;16(3):256-66. DOI: 10.1177/1474515116687178

19. Luttik M, Goossens E, Ågren S, Jaarsma T, Mårtensson J, Strömberg A, et al. Attitudes of nurses towards family involvement in the care for patients with cardiovascular diseases. Eur J Cardiovasc Nurs. 2017;16(4):299-308. DOI: 10.1177/1474515116663143

20. Mackie BR, Marshall A, Mitchell M, Ireland MJ. Psychometric testing of the revised "Families' Importance in Nursing Care-Nurses' Attitudes instrument". J Adv Nurs. 2018;74(2):482-90. DOI: 10.1111/jan.13442

21. Keogh B, Skärsäter I, Doyle L, Ellilä H, Jormfeldt H, Lahti M, et al. Working with families affected by mental distress: stakeholders' perceptions of mental health nurses educational needs. Issues Ment Health Nurs. 2017;38(10):822-8. DOI: 10.1080/01612840.2017.1341587

22. Skärsäter I, Keogh B, Doyle L, Ellilä H, Jormfeldt H, Lahti M, et al. Advancing the knowledge, skills and attitudes of mental health nurses working with families and caregivers: a critical review of the literature. Nurse Educ Pract. 2018;32:138-46. DOI: 10.1016/j. nepr.2018.07.002

23. Biscaia AR, Heleno LCV. A Reforma dos cuidados de saúde primários em Portugal: portuguesa, moderna e inovadora. Ciênc Saúde Coletiva. 2017;22(3):701-12. http://dx.doi.org/10.1590/1413-81232017223.33152016

24. Morosini MVGC, Fonseca AF, Lima LD. Política Nacional de Atenção Básica 2017: retrocessos e riscos para o Sistema Único de Saúde. Saúde Debate. 2018;42(116):11-24. DOI: http://dx.doi.org/10.1590/0103-1104201811601

25. Nóbrega MPSS, Silva GBF, Sena ACR. Psychosocial rehabilitation in the west network of the municipality of São Paulo: potentialities and challenges. Rev Gaúcha Enferm. 2018;39:e2017-0231. DOI: http://dx.doi.org/10.1590/1983-1447.2018.2017-0231

26. Barbiani R, Dalla Nora CR, Schaefer R. Nursing practices in the primary health care context: a scoping review. Rev Latino Am Enfermagem. 2016;24:e2721. DOI: 10.1590/1518-8345.0880.2721

27. Santos REB, Nóbrega MPSS. Saúde mental na atenção básica. Rev Baiana Enferm. 2017;31(4):e20134. DOI 10.18471/rbe.v31i4.20134

28. Fernandes AM, Mendes AMOC, Leitão MNC, Gomes SDL, Amaral AFS, Bento MCSSC. A contribuição da enfermagem portuguesa para o acesso e cobertura universal em saúde. Rev Latino Am Enfermagem. 2016;24:e2671. DOI: 101590/1518-8345.1068.2671 